\title{
Developing Mathematical Devices with Characteristics Realistic Mathematics Education
}

\author{
Melkior Wewe', I Wayan Juliawan' \\ 1,2 STKIP Citra Bakti Ngada-NTT; melkiorwewe1@gmail.com
}

\begin{abstract}
This research aims to generate a mathematics learning media characterized by valid and realistic mathematics education, describes the practicality of the learning media, and measures the results of the learning media toward the students' learning outcome. This study uses the ADDIE Model which consists of five stages, namely: analysis, design, development, implementation, and evaluation. The final products of this research are the lesson plan (RPP) and student worksheet (LKS) which are characterized by realistic mathematics education. Based on the results of the study, the validity analysis of the developed lesson plan and students' worksheet that is categorized as valid and in accordance with the classification of a good lesson plan and students' worksheet. After an assessment and revision of the learning media had been conducted, the implementation of the learning media was carried out. Based on the results of the analysis, the practicality of the product obtains an average score of $88.45 \%$ with the highly practical criteria. The analysis of students' responses toward the worksheet obtains an average score of 4.08 and has fulfilled the practical criteria. The analysis of the teacher's responses toward the worksheet obtains an average score of 4.58 and has fulfilled the practical criteria. The results of the pretest and posttest analysis show that the developed products have met the effective criteria because the percentage of students' completeness in the pretest was $58.65 \%$ and posttest was $81.9 \%$ which increased by $23.25 \%$.
\end{abstract}

Keywords: Mathematics Learning, Realistic Mathematics Learning.

\section{INTRODUCTION}

Changes in the education curriculum from the Education Unit Level Curriculum (KTSP) to the 2013 curriculum must be balanced with efforts to improve supporting facilities and infrastructure such as learning media. Learning media contained in the 2013 curriculum are expected to be able to improve the balance of attitudes, knowledge, and skills as a whole. The lack of availability of learning media, especially syllabus, lesson plans and teaching materials for students makes the learning process cannot run optimally.

The results of interviews with the teachers of elementary school (SD) IV in the Bajawa Sub-district in the Teacher Working Group (KKG) activity found that the teacher compiled learning media taken from references available on the internet. From the results of observation of learning media compiled by one of the class teachers, it was found that the stages in learning activities did not involve students as subjects of learning and did not show what character they wanted to improve through the stages of learning. Therefore, research is needed in developing learning media that suits their needs. Learning media can be developed through realistic mathematics education character learning model. Character includes knowledge of goodness, then promotes commitment (intention) towards goodness, and finally does the good deed. In other words, a character refers to a set of knowledge (cognitive), attitudes, and motivations, as well as behaviors and skills.(Lickona, 1991) 
The steps in realistic mathematics education character learning model in developing learning media include giving contextual problems, group discussions involving a horizontal and vertical mathematical process in the rediscovery of mathematical concepts, giving other problems relating to the material, and presentations. Learning media that will be produced consist of lesson plans (RPP) and student worksheet (LKS). By interacting with real things, it is hoped that students can build their knowledge in mathematics learning which emphasizes the use of real problems in the Realistic Mathematics Education model (PMR). In the education process, cultural education and national character are one of the efforts to prevent the degradation of ethical and moral values among adolescents. This sense of caring is based on the fact that today there is a tendency for the teenagers' behavior to deviates from the order of moral values that prevail in the community, which eventually leads to the teenager to be lost their path.

Several studies have been carried out to develop learning media in the form of RPP, LKS, and other forms of learning (Andari \& Lusiana, 2014; Asmawati \& Wuryanto, 2014; Febriana, Sulur, \& Yudyanto, 2014; Fitri, 2011; Hartono \& Noto, 2017; Indraningtias, Diah, \& Ariyadi Wijaya, 2017; Melisa, 2016; Nisak, 2013; Rizkiah, Nasir, \& Komarudin, 2018; Rudiono, Dafik, \& Wahyuningrum, 2015; A. U. Sari, Farida, \& Putra, 2017; F. K. Sari, Farida, \& Syazali, 2016; Sulistyowati \& Sugiman, 2014; Supiyati \& Jailani, 2014; Susanti, Musdi, \& Syarifuddin, 2017; Wijayanti \& Sungkono, 2017; Yusnita \& Subanti, 2014) and the use of Realistic Mathematics Education (PMR) model.(Ayunika et al., 2011; Bey \& Asriani, 2013; Putra, 2016; W. R. Sari, 2016; Syahputra, 2013; Wijaya, 2012) However, there have been no previous studies that developed learning media in the form of RPP and LKS characterized by Realistic Mathematics Education models. Based on the research that has been done before, the renewal in this study lies in the development of learning media in the form of RPP and LKS that characterize the Realistic Mathematics Education model. So, the purpose of this study is to produce a realistic mathematics education character learning media, to describe the practicality of learning media, and measure the mathematics learning outcomes.

\section{THE RESEARCH METHODS}

This research is research and development research. The development model used is the ADDIE model (Indraningtias et al., 2017). There are five steps of the development, namely: Analysis, Design, Development, Implementation, and Evaluation. The subjects in this study were fifth-grade students of SDN Watutura, Bajawa Subdistrict, Ngada District 2016/2017. Data obtained in this study were qualitative data (descriptive data during the development process) and quantitative data (input, responses, criticisms, suggestions, and improvements from the advisors, validators, teachers, and students). The instruments used in this study were the validity evaluation sheet, students and teachers questionnaire, learning implementation observation sheets and mathematics learning outcomes tests.

The data analysis techniques used in this study are as follow. The developed products were analyzed to obtain a valid product description. Data analysis was done to determine the 
quality of learning media in terms of validity, practicality, and effectiveness. The scoring of the results of learning media assessment was done using a Likert scale with the range score of 1-5.

Table 1. Assessment Scale Category / Classification in Five Theoretical validity Scale of the Learning Media

\begin{tabular}{cl}
\hline \multicolumn{1}{c}{ Range } & Classification \\
\hline Mi+1.5 SDi- $<$ MiSD +3.0i & Highly Valid \\
\hline Mi+0.5 SDi- $<$ Mi+1,5 SDi & Valid \\
\hline Mi-0,5 SDi- $<$ Mi+ 0,5SDi & Quite Valid \\
\hline Mi-1,5 SDi- $<$ Mi-0,5SDi & Invalid \\
\hline Mi- 3,0 SDi- $<$ Mi-1,5SDi & Highly Invalid \\
\hline
\end{tabular}

Description:

$\mathrm{M}_{\mathrm{i}} \quad=$ Ideal Mean $=\frac{1}{2}($ Ideal Maximum Score + Ideal Minimum Score $)$

$\mathrm{SD}_{\mathrm{i}} \quad=$ Ideal Standard Deviation $=\frac{1}{6}$ (Ideal Maximum Score + Ideal Minimum Score $)$

To find out the classification of scores obtained, it is converted into a five theoretical scale table (Koyan, 2012). It is said to be valid or practical if the learning media is at least qualified as valid or practical. The effectiveness analysis was carried out to determine the effectiveness of the learning media. The effectiveness data were obtained from the results of tests of mathematics learning outcomes using formulas $\bar{x}=\frac{\text { obtained score }}{\text { maximum score }} 100$, then calculate the percentage of completeness using formula $=\frac{\text { Number of students who reach completeness }}{\text { Total Number of Students }} \times 100 \%$.

Furthermore, the completeness criteria of students' mathematics learning outcomes were categorized based on the academic skills criteria as in Table 2

Table 2. Academic Skills Criteria (Mathematics Learning Outcomes Test)

\begin{tabular}{ccc}
\hline No & Percentage of completeness $(\mathrm{K})$ & Criteria \\
\hline 1 & $\mathrm{~K}>80$ & Excellent \\
\hline 2 & $60<\mathrm{K} \leq 80$ & Good \\
\hline 3 & $40<\mathrm{K} \leq 60$ & Moderate \\
\hline 4 & $20<\mathrm{K} \leq 40$ & Low \\
\hline 5 & $\mathrm{~K} \leq 20$ & Poor \\
\hline
\end{tabular}

Description:

$\mathrm{K}=$ Completeness Score

To find out the classification of effectiveness, the learning media must meet the good minimum criteria.

\section{THE RESULTS OF THE RESEARCH AND THE DISCUSSION}

The products developed in this study were mathematical learning media in the form of Lesson Plan and Student Worksheet with Realistic Mathematics Education models on Trapezoidal and Kite material. The results of the validity analysis of learning media are shown in Table 3. 
Table 3. Lesson Plan Validity Analysis

\begin{tabular}{|c|c|c|c|}
\hline No. & Aspect & Average & Classification \\
\hline 1 & Identity & 4 & Valid \\
\hline 2 & Accuracy of Time Allocation & 4 & Valid \\
\hline 3 & $\begin{array}{l}\text { Formulation of Objectives / } \\
\text { Indicators of Learning }\end{array}$ & 4 & Valid \\
\hline 4 & Teaching Materials & 4 & Valid \\
\hline 5 & $\begin{array}{l}\text { Election Approaches and } \\
\text { Learning }\end{array}$ & 4.67 & Highly Valid \\
\hline 6 & Learning Activity & 4,2 & Valid \\
\hline 7 & Selection of Learning Source & 4 & Valid \\
\hline 8 & Learning Outcome Assessment & 4 & Valid \\
\hline Total & & 32.87 & \\
\hline Average & & 4.10 & Valid \\
\hline
\end{tabular}

Table 3 is a summary of the analysis of the lesson plans' validity assessment by the validator. It obtained an average score of 4.10 with the obtained score of five (5) for each component of the assessment. After converting it to the scale table, 5 is in the valid category. The results obtained show that the lesson plan was developed according to the Minister of Education and Culture attachments I and II number 58 of 2014 concerning the 2013 curriculum.

Table 4. The Results of the Validity Analysis of the Student Worksheets

\begin{tabular}{cccc}
\hline No & Aspects & Average & Classification \\
\hline 1 & $\begin{array}{c}\text { Suitability of the Student Worksheet with } \\
\text { Constructive Requirements }\end{array}$ & 4.45 & Highly Valid \\
\hline 2 & $\begin{array}{c}\text { Suitability of Student Worksheet with } \\
\text { Realistic Mathematics Education } \\
\text { Approach }\end{array}$ & 4.67 & Highly Valid \\
\hline 3 & $\begin{array}{c}\text { Quality Content of the Student } \\
\text { Worksheet Material }\end{array}$ & 4 & Valid \\
\hline 4 & $\begin{array}{c}\text { Conformity of the Student Worksheet } \\
\text { with Didactive Requirements }\end{array}$ & 4 & Valid \\
\hline 5 & $\begin{array}{c}\text { Conformity of the Student Worksheet } \\
\text { with Technical Requirements }\end{array}$ & 4 & Valid \\
\hline Average & & 4,224 & \\
\hline
\end{tabular}

Table 4 is a summary of the results of the validity analysis of the student worksheets which obtained an average score of 4,224 with the obtained score of five (5) for each component of the assessment.

Table 5. The Summary of the Learning Implementation Analysis

\begin{tabular}{ccc} 
Meeting & Percentage of Implementation & Classification \\
\hline 1 & $84.61 \%$ & Very Practical \\
\hline 2 & $92.30 \%$ & Very Practical \\
\hline Average & $88.45 \%$ & \\
\hline
\end{tabular}


Table 5 is a summary of the implementation of the developed products. The result obtained was $88.45 \%$ within the highly practical criteria. These results prove that the developed lesson plan is well implemented by the teacher.

Table 6. The Summary of Questionnaire Analysis of Teacher's Responses toward the Lesson Plan

\begin{tabular}{lll}
\hline Research Instruments & Score & Classification \\
\hline Aspect of Assistance & 4.40 & Very Practical \\
\hline Aspect of Practicality & 4.67 & Very Practical \\
\hline Overall average & 4.58 & \\
\hline
\end{tabular}

Based on Table 6 , the aspect of assistance is 4.40 , the aspect of practicality is 4.67 , and the overall average is 4.58. Based on the results of the analysis, the developed learning media meets practical criteria from the students and teachers so that the developed learning media for the width and circumference of the material of the two-dimensional shape are very helpful and easy to use by the teachers in learning.

Table 7. The Summary Analysis of Student Questionnaire towards the Developed Worksheet

\begin{tabular}{lll}
\hline Research Instruments & Score & Classification \\
\hline The Aspect of Assistance & 4.07 & Practical \\
\hline The Aspect of Practicality & 4.1 & Practical \\
\hline Overall average & 4.08 &
\end{tabular}

From Table 7, the score of the aspect of assistance is 4.07, the score of the aspect of practicality is 4. 1, and the overall average score is 4.08. Based on the results of analysis of the student response questionnaire data, the results show that the developed student worksheet is fulfilling the practical criteria by students so that so that the developed learning media for the width and circumference of the two dimensional shapes material is very helpful and easy to be used by the students in learning.

Table 8. The Summary Analysis of Teacher Questionnaire towards the Developed Worksheet

\begin{tabular}{lll}
\hline Research Instruments & Score & Classification \\
\hline The Aspect of Assistance & 4.40 & Highly Practical \\
\hline The Aspect of Practicality & 4.67 & Highly Practical \\
\hline Overall average & 4.58 &
\end{tabular}

Based on table 8 , the score of the aspect of assistance is 4.40 , the score of the aspect of practicality is 4.67, and the overall average is 4.58 . Based on the results of an analysis of teacher questionnaire data on the developed worksheet characterized by realistic mathematical education models, it is known that learning media has met practical criteria because it is very helpful and easy in carrying out mathematics learning for fourth-grade students.

Table 9. Mathematics Learning Outcome

\begin{tabular}{lll}
\hline Mathematics Learning Outcome & average & Criteria \\
\hline Pretest & 58.65 & Not Completed \\
\hline Posttest & 81.9 & Completed \\
\hline
\end{tabular}


Based on the analysis of pretest and posttest in Table 9, it shows that the developed learning media has effectively met the criteria for the students' completeness since the average score in the pretest is $58.65 \%$ and posttest is $81.9 \%$ which increases by $23.25 \%$.

The developed product is learning media with Realistic Mathematics Education models developed with the ADDIE model through the stages of analysis, design, development, implementation, and evaluation. The steps for developing learning media by following the ADDIE development model are as follows. 1) Analysis. This stage was carried out before the planning stage in the product development process in the form of learning media on trapezoidal material and kites using the Realistic Mathematics learning model (PMR). At the analysis stage, the researcher conducted identification so that the developed product was in accordance with the character of students, learning objectives, learning materials, and learning environment. At the analysis stage, there were three activities carried out, namely: needs analysis, analysis of curriculum characteristics, and analysis of student characteristics. 2) Design. In the design stage, a detailed product concept design was made. This stage included the design of learning media in the form of lesson plan, student worksheet, and instruments. These designs were still conceptual and underlie the next development process. In addition, at this stage, an instrument design was used to measure products' performance by measuring the validity of the lesson plan and student worksheet, the student and teacher responses toward the questionnaires to measure the practicality, observation sheets for learning implementation to measure the effectiveness of the learning media, as well as the pretest and posttest to measure the effectiveness in terms of mathematics learning outcomes. 3) Development. The development stage was the stage of realization of product design. The product design that had been prepared in the planning stage was realized to be products to be implemented. In addition, an instrument was used to measure the performance of the products. Instruments made to measure product performance which included the lesson plan and student worksheet assessment sheets to measure validity, student and teacher's questionnaires to measure practicality, learning observation sheets to measure the effectiveness of learning media, and test results in the form of pretest and posttest to measure effectiveness in terms of ability in solving mathematics problems. At this stage, validation in the form of assessment and input to revise the developed learning media was conducted. The valid learning media will be tested in small group testing during learning activities to measure mathematics learning outcomes. 4) Implementation. In the implementation stage, the products were tested in real situations in the class. Tests were conducted to the research subjects to test the products' quality and learning outcomes on geometry material and the measurements of the realistic mathematics learning model. 5) Evaluation. The evaluation stage is where the objectives of product development are achieved. This stage measured the practicality and effectiveness of learning media in the form of a lesson plan, student worksheet, teacher handbooks, and learning outcomes from the test instruments on geometry and measurement materials developed using the realistic mathematics learning model. In addition, in measuring the achievement of the product development objectives, revisions to the product were carried out in accordance with the results of the evaluation or needs that cannot be fulfilled by the product. 
The next stage after going through the five stages is the final product in the form of mathematical learning media (lesson plan and student worksheet) characterized by the Realistic Mathematics Education model as follows: 1) the developed products have been assessed by a design expert and one mathematics teacher as a practitioner. From the results of the validity analysis of the lesson plan, the average score is 4.10 . After being converted to a scale table 5, it is in the valid category. The average score of the validity analysis of the student worksheet is 4,224 After being converted to Table scale 5, it is in the Valid category. The average score obtained shows that the lesson plan is in accordance with the good lesson plan according to the Minister of Education and Culture attachments I and II number 58 of 2014 concerning the 2013 curriculum. The average score obtained shows that worksheet with the realistic mathematics education model is compatible with the classification of a good worksheet.

Next, the assessment and revision of the learning media and the implementation of the learning media were carried out. From the results of the analysis, the practicality of the mathematics learning media characterized by the realistic mathematical learning model is as follows: 1) The average score of the learning implementation is $88.45 \%$ which belongs to the highly practical criteria. These results prove that the lesson plan developed using the stages of realistic mathematics learning is well implemented by the teacher. 2) The result of students' responses toward the worksheets on the aspects of assistance is 4.07, the aspect of convenience is 4.1 , and the overall average is 4.08 . Based on the results of the student questionnaire response data analysis, it can be concluded that the learning media has met the practical criteria by students so that the mathematics character learning in the realistic mathematical education model is very practical because it is very helpful and easy to use by students in learning. 3) The Analysis of teacher responses toward the lesson plan in the aspects of assistance is 4.40 , the aspect of convenience is 4.67 , and the overall average is 4.58 . Based on the results of the questionnaire data analysis of the teacher's response, the learning media has met the practical criteria by the teacher means that the developed product is very helpful and easy to use by teachers in learning

The results of pretest and posttest score analysis discover that the developed products are effective because of the average score in pre-test was $58.65 \%$ and posttest was $81.9 \%$, which increase by $23.25 \%$. The results of the study also found that the learning media developed could develop the character values of students because realistic mathematics education was closely related to the formation of character values like thinking critically and creatively, have a sense of curiosity, and confidence and independence. Only with strong character and innovative learning (realistic Mathematics Learning) is the national identity could be solid and the collaboration and competitiveness of the national increase in order to answer the challenges of the $21^{\text {st }}$ century.

The results of this study are reinforced by previous research related to the application of learning with realistic mathematical approaches. A research was carried out by Hasratuddin on the learning mathematics with a realistic mathematical approach is better than ordinary learning in improving students' critical thinking skills. This shows that realistic mathematical approaches have a good influence on learning (Indraningtias et al., 2017) The research conducted by Nunu 
Nurhayanti shows that learning media developed with Realistic Mathematics Learning can improve students' mathematical communication skills (Nurhayati, 2018). Thus, learning using realistic mathematical media approaches is very good and very suitable to be applied in the learning process. This is because, in the learning process, learning media can help to facilitate the implementation of learning.

\section{CONCLUSION AND SUGGESTIONS}

Based on the results of the research, the results of the validity analysis of the developed lesson plan and student worksheet have been categorized as valid and in accordance with the classification of a good lesson plan and student worksheet. After the assessment and revision of the learning media had been conducted, the implementation of the learning media was carried out. From the results of the analysis, the practicality of the average implementation of learning is $88.45 \%$ which belongs to the highly practical criteria. The average score of the student' responses toward the worksheet is 4.08 and have fulfilled practical criteria by students. The average score of teacher' response toward the student worksheet is 4.58 and has met the practical criteria by the teacher. The results of the pretest and posttest analysis showed that the mathematics character learning media generated by realistic mathematical education models fulfilled the criteria of effectiveness because the percentage of students' completeness in the pretest is $58.65 \%$ and posttest is $81.9 \%$, increasing by $23.25 \%$. Based on the conclusions of this study, it can be proposed a number of suggestions; namely, further researchers can try to develop other learning media using realistic mathematical education models or other learning models to maximize the learning.

\section{REFERENCES}

Andari, T., \& Lusiana, R. (2014). Pengembangan Perangkat Pembelajaran Dengan Menggunakan Pendekatan Quantum Learning Berbasis Needs Assesment Pada Materi Ruang-n Euclides. Jurnal Ilmiah Pendidikan Matematika, 3(1), 1-10.

Asmawati, R., \& Wuryanto. (2014). Keefektifan Model Pembelajaran LC 5E Dan TSTS Berbantuan LKPD Terhadap Hasil Belajar. Jurnal Kreano, 5(1), 26-32.

Ayunika, E., Sari, P., Studi, P., Matematika, P., Sanata, U., \& Yogyakarta, D. (2011). Pengembangan Hipotesis Trayektori Pembelajaran Untuk Konsep Pecahan. In Matematika dan Pendidikan Karakter dalam Pembelajaran (pp. 206-212).

Bey, A., \& Asriani. (2013). Penerapan Pembelajaran Problem Solving untuk Meningkatkan Aktivitas dan Hasil Belajar Matematika pada Materi SPLDV. Jurnal Pendidikan Matematika, 4(2), 223-239.

Febriana, L. C., Sulur, \& Yudyanto. (2014). Pengembangan Lembar Kerja Siswa (LKS) Fisika Materi Tekanan Mencakup Ranah Kognitif, Afektif dan Psikomotor Sesuai Kurikulum 2013 untuk Siswa SMP/MTs. Jurnal Universitas Negeri Malang, 2(1), 1-12.

Fitri, A. (2011). Pengembangan Perangkat Pembelajaran Statistika Dasar Bermuatan 
Pendidikan Karakter Dengan Metode Problem Based Learning. Jurnal PP, 1(2), 159-165.

Hartono, W., \& Noto, M. S. (2017). Pengembangan Modul Berbasis Penemuan Terbimbing untuk Meningkatkan Kemampuan Matematis pada Perkuliahan Kalkulus Integral. Jurnal JNPM ( Jurnal Nasional Pendidikan Matematika ), 1(2), 320-333.

Indraningtias, A., Diah, \& Ariyadi Wijaya. (2017). Pengembangan Perangkat Pembelajaran Berbasis Pendekatan Matematika Realistik Materi Bangun Ruang Sisi DatarBerorientasi Pada Kemampuan Berpikir Kritis Siswa Kelas VIIISMP. Jurnal Pendidikan Matematika, 6(5), 1-10.

Koyan, I. W. (2012). Statistik Pendidikan Teknik Analisis Data Kuantitatif. Singaraja: Universitas Pendidikan Ganesha Press.

Lickona, T. (1991). Educating for Character: How Our School Can Teach Respect and Responsibility. New York, Toronto, London, Sydney, Aucland: Bantam books.

Melisa. (2016). Pengembangan Modul Berbasis Penemuan Terbimbing Yang Valid Pada Perkuliahan Kalkulus Peubah Banyak 1. LEMMA, 1(2), 21-27.

Nisak, K. (2013). Pengembangan Perangkat Pembelajaran IPA Terpadu Tipe Connected pada Materi Pokok Sistem Ekskresi untuk kelas IX SMP. Jurnal Pendidikan Sains, 1(1), 8184.

Nurhayati, N. (2018). Pengembangan Perangkat Bahan Ajar Pada Pembelajaran Matematika Realistik Indonesia Untuk Meningkatkan Kemampuan Komunikasi Matematis Siswa. Fibonacci : Jurnal Pendidikan Matematika Dan Matematika, 3(2), 121-136.

Putra, F. G. (2016). Pengaruh Model Pembelajaran Reflektif dengan Pendekatan Matematika Realistik Bernuansa Keislaman terhadap Kemampuan Komunikasi Matematis. Al-Jabar: Jurnal Pendidikan Matematika, 7(2), 203-210.

Rizkiah, A. W., Nasir, \& Komarudin. (2018). LKPD Discussion Activity Terintegrasi Keislaman dengan Pendekatan Pictorial Riddle pada Materi Pecahan. Desimal : Jurnal Matematika, 1(1), 39-47.

Rudiono, T., Dafik, \& Wahyuningrum, E. (2015). Pengembangan Perangkat Pembelajaran Berbasis Rme Berorientasi Terciptanya Berfikir Tingkat Tinggi Materi Perbandingan Kelas VII. Pancaran, 4(1), 45-54.

Sari, A. U., Farida, \& Putra, F. G. (2017). Pengembangan Media Pembelajaran Berbantuan Web Dengan Pendekatan Etnomatematika Pada Pokok Bahasan Bangun Ruang Sisi Datar. In Prosiding Seminar Nasional Matematika dan Pendidikan Matematika (pp. 209-214). Lampung.

Sari, F. K., Farida, \& Syazali, M. (2016). Pengembangan Media Pembelajaran (Modul) berbantuan Geogebra Pokok Bahasan Turunan. Al-Jabar: Jurnal Pendidikan Matematika, $7(2), 135-151$.

Sari, W. R. (2016). Pengembangan Perangkat Pembelajaran Bangun Ruang di SMP dengan Pendekatan Pendidikan Matematika Realistik. Jurnal Riset Pendidikan Matematika, 3(1), 
$109-121$.

Sulistyowati, Y., \& Sugiman. (2014). Pengembangan Perangkat Pembelajaran Bangun Ruang di SMP dengan Pendekatan Creative Problem Solving. Phytagoras, 9(2), 219-232.

Supiyati, \& Jailani. (2014). Pengembangan Perangkat Pembelajaran Bangun Ruang SMP dengan Pendekatan SAVI ( Somatik, Auditori, Visual, Intelektual). Jurnal Pendidikan Matematika, 9(2), 175-185.

Susanti, Musdi, E., \& Syarifuddin, H. (2017). Pengembangan Perangkat Pembelajaran Matematika Materi Statistik Berbasis Penemuan Terbimbing Untuk Meningkatkan Kemampuan Pemecahan Masalah Matematis Materi Statistika. Jurnal JNPM ( Jurnal Nasional Pendidikan Matematika ), 1(2), 305-319.

Syahputra, E. (2013). Peningkatan Kemampuan Spasial Siswa Melalui Penerapan Pembelajaran Matematika Realistik. Cakrawala Pendidikan, 32(3), 353-364.

Wijaya, A. (2012). Pendidikan Matematika Realistik: Suatu Alternatif Pendekatan Pembelajaran Matematika. Yogyakarta: Graha Ilmu.

Wijayanti, S., \& Sungkono, J. (2017). Pengembangan Perangkat Pembelajaran mengacu Model Creative Problem Solving berbasis Somatic, Auditory, Visualization, Intellectually. AlJabar: Jurnal Pendidikan Matematika, 8(2), 101-110.

Yusnita, R., \& Subanti, S. (2014). Pengembangan Perangkat Pembelajaran Berbasis Penemuan Terbimbing (Guided Discovery) Dengan Pendekatan Somatic, Auditory, Visual, Intellectual (SAVI) Pada Materi Pokok Peluang Kelas IX SMP Tahun Pelajaran 2013/2014. Jurnal Elektronik Pembelajaran Matematika, 2(4), 379-388. 